http://dx.doi.org/10.18778/1508-1117.24.02

Anna Kołodziejczak

\title{
THE CONCEPTION OF EMBEDDEDNESS IN RESEARCH ON LOCAL DEVELOPMENT: A STUDY OF SIERAKÓW
}

\begin{abstract}
This article presents the conception of embeddedness, which offers a new look at the development of rural areas based on their endogenous resources and the stimulation of their communities. The case in point will be the conditions and resources of the commune of Sieraków, located in the north-western part of Wielkopolska voivodeship in Poland, that contribute to its local development. Ways will be presented of reinforcing embeddedness, so as to help the commune keep as much as possible of the value added produced by the activity (agricultural and non-agricultural) of its residents, assisted by an efficient use of endogenous resources and geared to its further development.
\end{abstract}

Key words Embeddedness, local development, Sieraków.

\section{Introduction}

There are a variety of approaches to and interpretations of the conception of embeddedness, which makes it hard to employ in empirical studies. This notion, not defined too precisely in the literature, comes from the social anthropologist K. Polanyi (1944). He was of the opinion that the economy was not autonomous, as the classic economic theories would have it, but depended on social relations or politics. For Polanyi embeddedness meant a dependence between economic behaviour and social relations. The next scholar to tackle embeddedness was M. Granovetter (1985), who believed that economic entities did not make decisions in abstraction from the social context, and that their goal-oriented actions were embedded in concrete systems of current social relations. A significant role is played by the complex relations that hold among the participants of economic processes and that create networks. It is in them that individuals and firms and their economic behaviour are embedded.

The conception of embeddedness has been adapted to the specific nature of spatial-economic studies. Here it is understood as the rooting of various entities in 
a certain milieu or surroundings as well as in a regional structure or local practices (Grzeszczak 1999, p. 57).

According to M. Hess (2004), entities are embedded in networks of relations and institutions, and the basic spatial scale of their analysis is a local or a regional one.

The dynamic development of the conception of embeddedness started in the mid-1990s when it was employed to give socio-economic phenomena a geographical description and explanation (Grabher 1994; Dicken et al. 1994; Saxenian 1994; Park 1996; Oinas 1998; Grzeszczak 1999; Stryjakiewicz 1999, 2004; Dicken, Malmberg 2001; Domański 2003, 2004). With all those various approaches, K. Stachowiak (2011) distinguishes the following forms of embeddedness:

1. Structural, which means the relationship between the behaviour of economic entities and the social structure in which they operate; this structure can restrict or aid their activity;

2. Cognitive, which means links between the behaviour of economic entities and cognitive processes (restricted rationality, subjectivity of information);

3. Cultural, which means a connection between the behaviour of economic entities and broadly understood culture, i.e. the patterns of thinking and acting, norms, values, skills and knowledge characteristic of a society; economic culture plays a role in development by creating an informal framework for economic activity specific to the given place or region;

4. Political, which means connecting the behaviour of economic entities with political processes or structures;

5. Institutional, which means connecting economic behaviour with institutions, i.e. economic rules that govern relations between entities; and

6. Spatial, which means connecting entities with a specified area and processes occurring there. It combines elements of the other forms of embeddedness cultural, political or institutional - limited to a concrete territory. Z. Chojnicki $(1999$, p. 318) defines a territory as ,an area on the Earth's surface, together with its material, natural and artificial contents, effectively controlled by a human community".

In reality, all those forms of embeddedness are interconnected and rarely appear in isolation, which follows from the complexity and multi-dimensionality of social life.

This paper seeks to present the conception of embeddedness that can stimulate the development of rural areas based on the assets they possess. The case in point will be the conditions and resources of the commune of Sieraków that contribute to its development. The analysis rested on Central Statistical Office data as well as information and strategic documents obtained from the Sieraków Commune Office. The fieldwork embraced making an inventory, a survey research among residents and tourists in the summer of 2014, and interviews with representatives of various institutions and associations operating in the commune, including the Noteć Forest Local Action Group, the Obra-Warta Local Fishing Group, the Wielkopolska Complex of Landscape Parks, and the Sieraków Forest Inspectorate. 


\section{The conception of embeddedness and local development}

The conception of embeddedness presupposes the use of an area's local resources for its development, both economic and social. It is an effect of changes in thinking about functions and goals of rural development. Embeddedness is connected with the idea of sustainable development which, in the opinion of T. Adamski and K. Gorlach (2007), implies the adoption of a transformation strategy that will not do any harm to the natural, economic and social resources located in an area, thus allowing its development to continue in the future. Sustainable development rests on a neo-endogenous mechanism which assumes that, apart from mass participation of local actors, it is necessary to engage supra-local ones: regional authorities, non-governmental organisations operating on a larger scale, and even the central government.

Embeddedness means that there develops a peculiar socio-economic system of interrelations in an area which, by proper management of resources (whether or not formalised), makes it possible to keep a maximum of profits and advantages deriving from them in the area for the use of the local community and its development. It should be emphasised that the local development of an area follows from social and economic determinants, and that it is always embedded in a concrete institutional milieu. Often of no little importance in shaping it are local governments and various organisations, like local action groups, economic chambers, agricultural associations and cooperatives, or even parishes. In a local development model based on the conception of embeddedness, economic processes (production, distribution, consumption) are activities that share local resources and flows of goods, both material and non-material (services), taking place in an area (fig. 1). What is significant is assigning a value to an asset (a landscape, an activity, a skill of residents) closely connected with the area where it occurs. Thus distinguished, the asset gives rise to processes in which there develop a variety of relations among local actors: economic entities, the community, self-government, and organisations. Within those diverse micro-structures, the activities and relations holding among their participants determine the nature of the local economy, while interaction networks are shaped by power relations. In the opinion of P. Dicken (2004), the most important factors influencing the relative power of actors, and thus affecting local development, are control over the key local assets possessed and the spatial scope of activity.

It can be stated that the idea underlying the conception of embeddedness is the use of strictly local, endogenous resources based on cooperation of residents offering their products and services on the market. Then as much as possible of the value added by the activity of the residents will be kept in the area and will serve local development (Jasiński et al. 2014). 


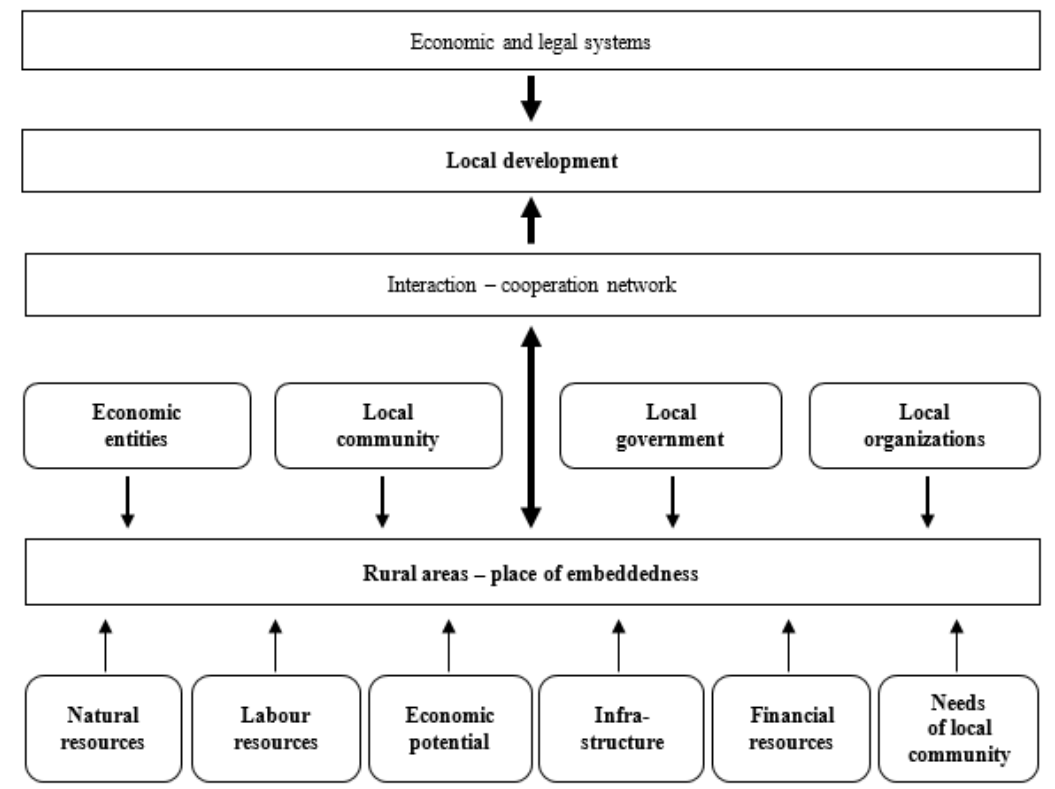

Fig. 1. Local development model based on the conception of embeddedness

Source: A. Kołodziejczak

\section{Local determinants of the development of Sieraków}

The urban-rural commune of Sieraków is a case well illustrating the practical rules of embeddedness based on comprehensive tourist services. It is located in the western part of Wielkopolska voivodeship, in Międzychód poviat, some 70-85 km north-west of Poznań. Situated in the Poznań Lakeland, it is cut in the central part by the Warta river. The north is occupied by the Noteć Forest. The characteristic elements of the commune landscape are woods and lakes. Woodland accounts for the greatest proportion of the total area $(57 \%)$, followed by farmland $(28.5 \%)$, water bodies ( $8 \%$ ) and built-up areas (5.5\%). The settlement system of the commune includes the town of Sieraków and 15 villages (fig. 2).

The villages differ in their population number. In 2013 the commune had 8,770 inhabitants of whom 6,117 lived in the town. The commune is rich in natural resources. To protect its nature and the postglacial landscape, the Sieraków Landscape Park was established in 1991 in its central and southern parts, with the seat at Chalin. Half of the Park, i.e. $153 \mathrm{~km}^{2}$, occupies $75 \%$ of the commune area; the other half lies in three neighbouring communes. There are four reserves in the park. The entire northern part of the commune is covered by the second largest woodland complex in Poland, the Noteć Forest. In the south the woods are more diversified, partly broad-leaved. There are three NATURA 2000 areas: 


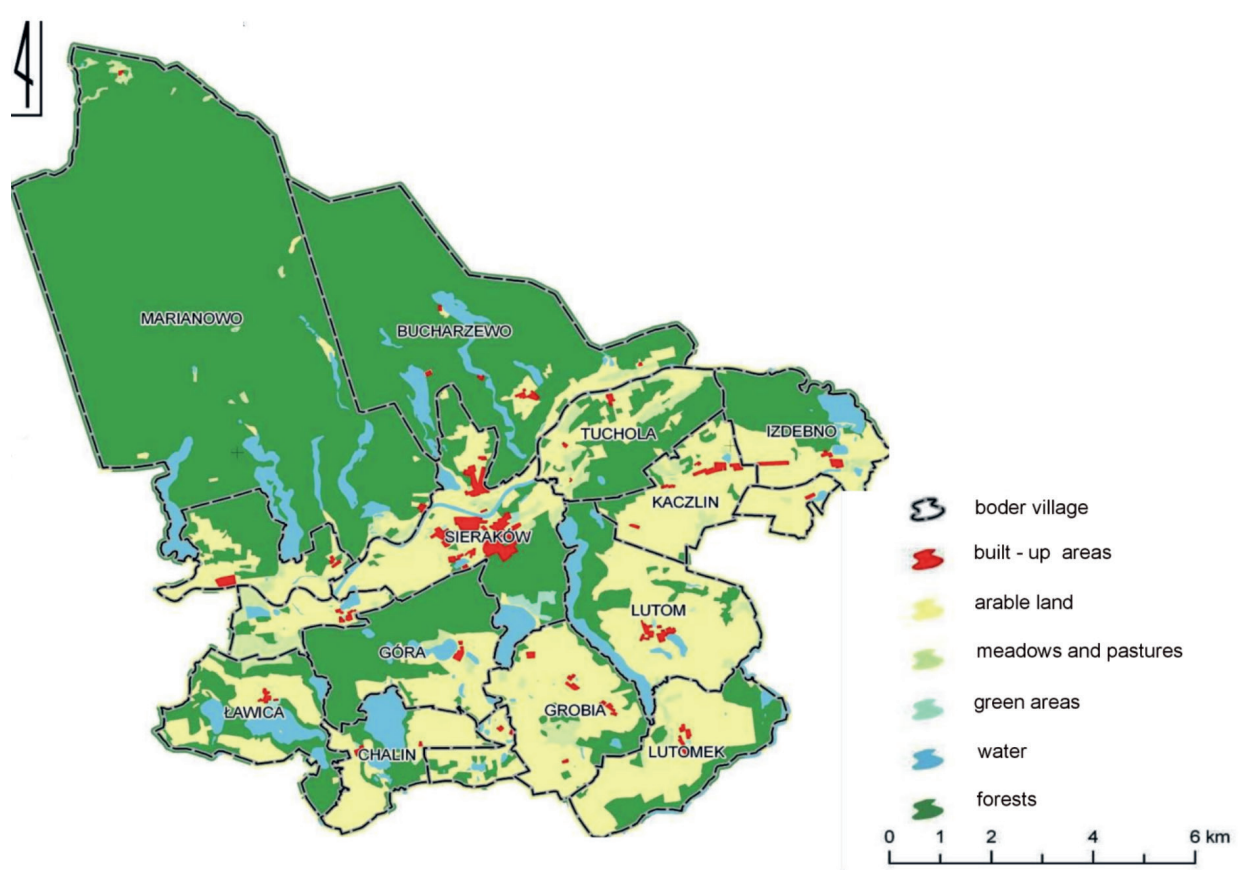

Fig. 2. Land-use pattern in the commune of Sieraków

Source: A. Świderski

the Sieraków Refuge, the Noteć Forest, and Lake Kubek. The entire area lies in the basin of the Warta river, which cuts the commune latitudinally. The Warta is a transport corridor, part of the Great Wielkopolska Loop water trail. There are many lakes totalling 1,280 ha in area, which gives the commune a lake percentage of $6 \%$, despite the water-poor northern part. Such a high index distinguishes the commune in the Wielkopolska-Kujavia Lakeland with its average lake percentage of $1.23 \%$ (Choiński 2007).

With those natural resources, Sieraków is a recreational commune operating as a tourist hinterland of Poznań. In the opinion of tourists, Sieraków means woodland and water bodies. In the summer visitors come here for its lakes, in the autumn, to pick mushrooms, and in the winter and spring, to explore tourist trails, to ride horses, and to relax. The commune's index of tourist traffic intensity (Schneider's index) as expressed by the number of tourist beds per 1,000 residents amounts to 5,187 (Szromek 2012), seven times as high as the average for Poland (724) and more than twice the average for Międzychód poviat (2,047). The number of tourists per bed in the commune of Sierakow is 51, which is much higher than the average for Międzychód poviat (36.2) and the national mean (48.7; Kaczmarek 2014). 
The commune of Sieraków performs agricultural and tourist functions. In $2013,39.4 \%$ of its residents worked in agriculture, while services accounted for $32.6 \%$ of total employment. The unemployment coefficient was low, at $4.5 \%$. The economic potential of the commune rests on 400 agricultural holdings and 500 economic entities, most of them active in trade, tourism and construction. The largest plants are the Warta-Glass glassworks in Sieraków, the ABP Poland meat plant with Irish capital at Kłosowice, and the Podolski commercial-manufacturing firm at Lutomek.

The commune is crossed by voivodeship, poviat and commune roads. The road network is better developed in the south and less dense in the north, which makes it less accessible by car. Across the commune runs a non-electrified single-track Szamotuły-Międzychód railway line (operating in the summer and autumn as a tourist attraction). The commune has a well-developed water-pipe network, but a poorly developed sewage system. It is a member of the Noteć Forest Local Action Group and the Obra-Warta Local Fishing Group. Almost 50\% of its outlays go to tourism.

What is very important when making natural resources available to the public is their tourist development. In the commune there are trails of various length belonging to many administrators, e.g. local governments at the voivodeship, poviat and commune levels, the Managing Board of the Landscape Parks of Wielkopolska Voivodeship, the State Forests, and the Polish Tourist and Sightseeing Society. Those various entities finance the marking of those trails and the information about them. The commune of Sieraków has a dense network of hiking routes, totalling about $200 \mathrm{~km}$ in length. This is complemented by didactic paths, which can be found, e.g., near Lake Lutomskie or in the Chalin area. The commune's bike trails are connected with the Wielkopolska System of Bike Trails. Its density of about $85 \mathrm{~km}$ of bike trails per $100 \mathrm{~km}^{2}$ places the commune among the best in the voivodeship. Crossing the commune is the Wolf's Horse-Riding Trail, with an intended ultimate length of $240 \mathrm{~km}$, which allows horse-riding excursions of several days' duration. There are also three canoe trails in the commune. One of them, located on the Warta river, is marked as part of the Great Wielkopolska Loop. Launching sites and places offering tourist services can be found in Sieraków and Chorzępowo.

The location of and spatial differences in the commune's assets make it possible to distinguish four tourist zones (fig. 3):

- Zone A, embracing areas around lakes Jaroszewskie and Lutomskie. The area is attractive in terms of landscape (lakes, woods, a reserve) and sporting-recreational facilities, as well as the tradition of active tourism. The forms especially recommended in this zone are water-related, recreational and sport tourism;

- Zone B, embracing the city centre. The centrally located city is a link between the northern and the southern parts of the commune via the only bridge on the 
Warta river. The centre has several cultural attractions (the Opaliński castle, a stud farm, the market, the Warta river, churches), while its other assets justify initiating culinary tourism and developing cultural, horse-riding and Warta-related tourism:

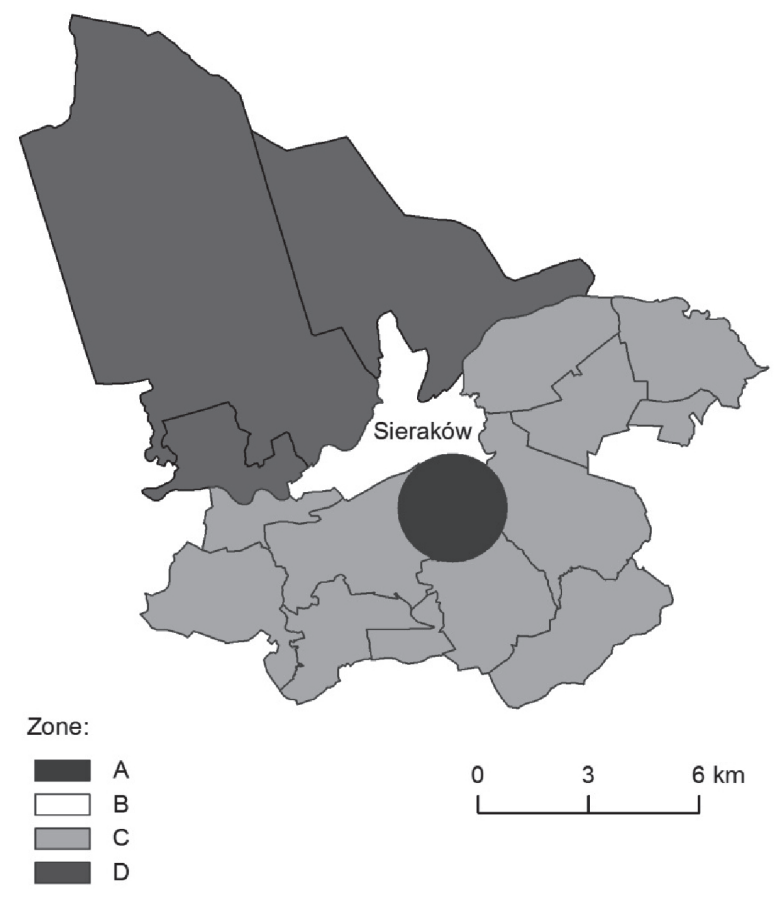

Fig. 3. Tourist zones in the commune of Sieraków

Source: A. Kołodziejczak

- Zone $\mathrm{C}$, embracing the southern part of the commune's rural areas. It boasts a natural environment attractive in tourist and recreational terms because of a variety of landscapes (a diversified relief, numerous lakes in forest-agricultural surroundings) and legally protected natural curiosities (a landscape park, reserves, monuments of nature, NATURA 2000 areas). The forms of tourism that should develop in this zone are educational, cycling, cultural, and rural (agritourism and ecotourism);

- Zone D, embracing the northern part of the commune on the other bank of the Warta, namely the woodland areas of the Noteć Forest. Its resources, combined with the tendencies on the regional tourist market, allow the development of agritourism, ecotourism, cycling, horse-riding, hiking, water-based tourism, and tourism for blind people. 
The adaptation of assets to tourist use requires taking appropriate organised measures that make it easier and more attractive to visit them, but also that secure areas valuable in natural terms against devastation by tourists. The scope and scale of measures taken can vary greatly, depending on the type and spatial structure of the assets and the forms of tourist traffic developing in an area. In the case of the commune of Sieraków, by proper management of the local resources, tourism allows keeping a maximum of profits and advantages deriving from it for the use of the local residents and development. Of great significance in this respect is the local government, which engages in cooperation with institutional partners. Because the commune belongs to a network of tourist products of Wielkopolska, it is expected to cooperate with the authorities of Międzychód poviat and Wielkopolska voivodeship. An increase in the number of tourists visiting the commune requires the involvement of all persons engaged in the organisation and promotion of tourism, hence the commune cooperates with the Wielkopolska Tourist Organisation, the Wielkopolska Complex of Landscape Parks, the Sieraków Forest Inspectorate, and the Sieraków Stud Farm. The commune also remembers theme-related partners connected with individual measures, like the Noteć Forest Local Action Group, the Obra-Warta Local Fishing Group, or the Barrier-Free Countryside Association. Tourist development requires support for plans and initiatives as well as new forms of social activity, therefore the commune cooperates with culture-promoting institutions and organisations: the Opaliński castle, the Sieraków Cultural Centre, the Society of the Sieraków Land Lovers, or the Shooting Society, as well as sports institutions and organisations.

The numerous measures and ventures undertaken by the local government and community of the commune of Sieraków boost employment and help to improve the quality of life of its residents. It was necessary to choose directions of the commune's tourist development, hence its cooperation with the Institute of Socio-Economic Geography and Spatial Management and the Tourism and Recreation Chair of Adam Mickiewicz University in Poznań on such a strategy up to 2020. It was intended to determine the mission and the vision, or strategic goals, of tourist development here and to create brand-name tourist products involving the use of the local resources.

\section{Conclusions}

Development based on the conception of embeddedness relies on the common resources of goods deriving from the local specificity, endogenous raw materials, and skill in their development. Those conditions are met by the commune of Sieraków, where common resources have been identified, appreciated, and put to ever wider use. The local authorities run successive development projects employing those well-identified local resources. There are still many possibilities of reinfor- 
cing the development on the basis of the conception of embeddedness because, while the residents and tourists visiting the commune are aware of the commune's brand name and its worth, it promotes the place rather than the products. The commune and its brand-name tourist products lack an expressive image. The Strategy for the development of tourism in the commune of Sieraków until 2020, drawn up by a team of Adam Mickiewicz University research workers, is intended to establish tasks in this field that should be carried out under the direction of the local authorities.

At this point I would like to thank the commune authorities, who ordered the preparation of the Strategy for the development of tourism in the commune of Sieraków until 2020, all persons who have contributed to it by their opinions and involvement, and those who have given us a lot of important information about tourism in the commune in the course of interviews.

\section{BIBLIOGRAPHY}

Adamski T., Gorlach K., 2007, Koncepcja rozwoju neo-endogennego, czyli renesans znaczenia wiedzy lokalnej (Conception of neo-endogenous development, or the revival of the importance of local knowledge), [in:] Gorlach K., Niezgoda M., Seręga Z. (eds), Socjologia jako stużba społeczna. Pamięci Władysława Kwaśniewicza, Wydawnictwo UJ, Kraków, p. 137-150.

Choiński A., 2007, Limnologia fizyczna Polski (Physical limnology of Poland), Wydawnictwo Naukowe UAM, Poznań.

Chojnicki Z., 1999, Podstawy metodologiczne i teoretyczne geografii (Methodological and theoretical foundations of geography), Bogucki Wydawnictwo Naukowe, Poznań.

Dicken P., Kelly P.F., Olds K., Yeung H.W.-C., 1994, The local embeddedness of transnational corporations, [in:] Amin A., Thrift N. (eds), Globalization, institutions and regional development in Europe, Oxford University Press, Oxford, p. 23-45.

Dicken P., Malmberg A., 2001, Firms in territories: A relational perspective, „Economic Geography", 77(4), p. 345-363.

Dicken P., 2004, Geographers and ,globalization': (yet) another missed boat?, „Transactions of the Institute of British Geographers", 29(1), p. 5-26.

Domański B., 2003, Transnational corporations in Polish manufacturing. Their embeddedness and impact on Poland's role in the European economy, [in:] Kukliński A., Skaza B. (eds), Europe in the perspective of global change, The Polish Association for the Club of Rome, Oficyna Wydawnicza Rewasz, Warszawa, p. 315-322.

Domański B., 2004, Local and regional embeddedness of foreign industrial investors in Poland, [in:] Paszkowski M. (ed.), Effectiveness, geographical space, quality of life, „Prace Geograficzne”, 114, Instytut Geografii i Gospodarki Przestrzennej UJ, Kraków, p. 37-54.

Grabher G., 1994, The disembedded regional economy: The transformation of East German industrial complexes into Western enclaves, [in:] Amin A., Thrift N. (eds), Globalization, institutions and regional development in Europe, Oxford University Press, Oxford, p. 177-195. 
Granovetter M., 1985, Economic action and social structure: The problem of embeddedness, „American Journal of Sociology”, 91(3), p. 481-510.

Grzeszczak J., 1999, Bieguny wzrostu a formy przestrzeni spolaryzowanej (Growth poles and forms of polarised space), „Prace Geograficzne”, 173, IGiPZ PAN, Warszawa.

Hess M., 2004, 'Spatial' relationships? Towards a reconceptualization of embeddedness, „Progress in Human Geography”, 28(2), p. 165-186.

Jasiński J., Michalska S., Śpiewak R., 2014, Rynki zakorzenione - koncepcja uruchomienia mechanizmów lokalnego rozwoju (Embedded markets: A conception of starting local development mechanisms), „Wieś i Rolnictwo”, 3(164), p. 105-123.

Kaczmarek U., 2014, Baza noclegowa i ruch turystyczny (Accommodation base and tourist traffic), [in:] Kołodziejczak A. (ed.), Strategia rozwoju turystyki w gminie Sieraków do 2020 r., CD version, p. 32-36.

Oinas P., 1998, The embedded firm? Prelude for a revived geography of enterprise, „Acta Universitatis Oeconomicae Helsingiensis", A-143, Helsinki School of Economics and Business Administration, Helsinki.

Park S.O., 1996, Networks and embeddedness in the dynamic types of new industrial districts, „Progress in Human Geography”, 20(4), p. 476-493.

Polanyi K., 1944, The great transformation: The political and economic origins of our time, Beacon Press, Boston.

Saxenian A., 1994, Regional advantage: Culture and competition in Silicon Valley and Route 128, Harvard University Press, Cambridge.

Stachowiak K., 2011, Rola koncepcji zakorzenienia w geograficznych badaniach nad globalizacja (Role of the concept of embeddedness in geographical research on globalization), Podstawowe idee i koncepcje w geografii, t. 1, p. 83-99.

Strategia rozwoju turystyki w gminie Sieraków do 2020 roku (Strategy for the development of tourism in the commune of Sieraków until 2020), 2015, CD version.

Stryjakiewicz T., 1999, Adaptacja przestrzenna przemystu $w$ Polsce $w$ warunkach transformacji (The spatial adaptation of industry in Poland in the conditions of transformation), „Seria Geografia”, 61, Wydawnictwo Naukowe UAM, Poznań.

Stryjakiewicz T., 2004, Sieci gospodarcze $w$ Polsce $w$ warunkach transformacji (Economic networks in Poland in the conditions of transformation), [in:] Parysek J. (ed.), Rozwój regionalny i lokalny w Polsce w latach 1989-2002, Bogucki Wydawnictwo Naukowe, Poznań, p. 25-44.

Szromek A., 2012, Wskaźniki funkcji turystycznej. Koncepcja wskaźnika funkcji turystycznej $i$ uzdrowiskowej (Indices of the tourist function. The conception of an index of a tourist and spa function), Wydawnictwo Politechniki Śląskiej, Gliwice.

\section{KONCEPCJA ZAKORZENIENIA W BADANIACH NAD ROZWOJEM LOKALNYM - STUDIUM SIERAKOWA}

Zarys treści W artykule przedstawiono koncepcję zakorzenienia, która jest nowym spojrzeniem na możliwość rozwoju lokalnego obszarów wiejskich w oparciu o występujące tam zasoby endogenne oraz mechanizm stymulowania społeczności. W tym kontekście pokazane zostały warunki i zasoby gminy miejsko-wiejskiej Sieraków położonej 
w północno-zachodniej części województwa wielkopolskiego, które przyczyniają się do jej rozwoju lokalnego. Sieraków w oparciu o zasoby przyrodnicze jest gminą wypoczynkową, stanowiąc turystyczne zaplecze Poznania. Przystosowanie walorów do użytkowania turystycznego wymaga podjęcia odpowiednich zorganizowanych działań, które z jednej strony powinny ułatwiać i uatrakcyjniać ich zwiedzanie, drugiej - zabezpieczać przed niszczeniem przez turystów obszarów cennych przyrodniczo. Gmina Sieraków jest przypadkiem dobrze ilustrującym praktyczne zasady zakorzenienia opartego na kompleksowej usłudze turystycznej.

Słowa kluczowe Koncepcja zakorzenienia, rozwój lokalny, Sieraków.

Dr hab. Anna Kołodziejczak, prof. UAM Instytut Geografii Społeczno-Ekonomicznej i Gospodarki Przestrzennej Wydział Nauk Geograficznych i Geologicznych Uniwersytet im. Adama Mickiewicza w Poznaniu 